\title{
The Role of Adjuvant Radiotherapy in the Treatment of Papillary Tumors of the Pineal Region: Some General Considerations and a Case Report
}

\author{
Role adjuvantní radioterapie při léčbě papilárních nádorů \\ pineální oblasti: kazuistika a krátký přehled literatury
}

\author{
Lancia A., Ingrosso G., Santoni R. \\ Department of Diagnostic Imaging, Molecular Imaging, Interventional Radiology and Radiotherapy, Tor Vergata General Hospital, Rome, Italy
}

\begin{abstract}
Summary
Background: Papillary tumor of the pineal region (PTPR) is a recently defined tumor entity. Its clinical course is characterized by frequent local recurrence, and patients may experience the burden of symptoms due to the anatomical location of the growing mass. Guidelines for treatment protocols, and the role of radiotherapy are still being investigated. Case: We report the case of a 27-year old woman who was referred to our department after she was diagnosed with PTPR and had undergone multiple surgical interventions. We delivered adjuvant conformal radiotherapy on the gross residual tumor to a total dose of $59.4 \mathrm{~Gy}(33 \times 1.8 \mathrm{~Gy})$. Discussion: After a follow-up period of 41 months, we obtained a complete response to the treatment, according to the Response evaluation criteria in solid tumors criteria (RECIST). Radiation treatment was well tolerated, and the patient did not develop acute and late side effects. The neurological symptoms, which were documented at the diagnosis and after the surgical procedure, have not been recorded at last follow-up. Conclusions: Formal consensus for managing patients with a diagnosis of PTPR are nonexistent. Despite surgery, this tumor has a tendency to recur. Radiotherapy could have a role in the adjuvant setting and needs to be investigated in a multicenter setting with a long follow-up.
\end{abstract}

Key words

radiotherapy - neurosurgery - magnetic resonance - pineal region - brain tumor

\section{Souhrn}

Úvod: Papilární nádory pineální oblasti (papillary tumor of the pineal region - PTPR) jsou vzácné nedávno definovanené nádory. Jejich klinický průběh je charakterizován častou lokální recidivou a pacienti mohou mít příznaky kvůli anatomickému nálezu zvětšující se nádoru. Léčebné protokoly a role adjuvantní radioterapie jsou stále nejednoznačné. Kazuistika: Uvádíme případ 27leté ženy, která byla odeslána na naše pracoviště potom, co jí byl diagnostikován PTPR, a která podstoupila několik operačních zákroků. Použili jsme adjuvantní radioterapii v celkové dávce 59,4 Gy (33 × 1,8 Gy). Diskuze: Při době sledování 41 měsíců bylo dosaženo kompletní odpovědi na léčbu podle kritérí RECIST. Radioterapie byla dobře snášena bez akutních a pozdních vedlejších účinků. Neurologické symptomy, které byly přítomny v době diagnózy a po chirurgickém zákroku, nebyly při poslední kontrole zaznamenány. Závěry: Formální konsenzus pro management pacientů s diagnózou PTPR neexistuje. Navzdory radikální operaci má tento nádor tendenci k častým recidivám. Radioterapie může mít význam již v adjuvantní indikaci, pro přesné zhodnocení její role jsou však nutné prospektivní multicentrické studie s dostatečně dlouhou dobou sledování.

\section{Klíčová slova}

radioterapie - neurochirurgie - magnetická rezonance - pineální oblast - mozkový nádor
The authors declare they have no potentia conflicts of interest concerning drugs, products, or services used in the study.

Autoři deklarují, že $v$ souvislosti s předmětem studie nemají žádné komerční zájmy.

The Editorial Board declares that the manuscript met the ICMJE recommendation for biomedical papers.

Redakční rada potvrzuje, že rukopis práce splnil ICMJE kritéria pro publikace zasílané do biomedicínských časopisů.

\section{Andrea Lancia, MD}

Department of Diagnostic Imaging Molecular Imaging, Interventional

Radiology and Radiotherapy

Tor Vergata General Hospital Viale Oxford 81

00133 Rome

Italy

e-mail: andrea.lancia@alice.it

Submitted/Obdrženo: 25. 7. 2017

Accepted/Príijato: 20. 8. 2017

doi: 10.14735/amko2017456 


\section{Introduction}

Neoplasms occurring in the pineal region are rare and correspond to less than $1 \%$ of all intracranial tumors. Within this group, papillary tumor of the pineal region (PTPR) was described for the first time as a distinct clinical-pathological lesion by Jouvet et al in 2003 [1], and was eventually included in the WHO classification of tumors of the nervous system only in 2007 [2].

In the current WHO 2016 classification [3], PTPR represents one of the four different nosographic entities, which are enclosed in the group of tumors of the pineal region. It is difficult to distinguish these particular tumors from the others, especially pineocytomas. They are usually described in the imaging studies as mildly lobulated, partially cystic masses, which are heterogeneously hyperintense in the T2-weighted MRI. However, the non-contrast T1-weighted imaging, which often reveals low or intermediate intensity, can also describe hyperintensity of these lesions in some patients, due to the high concentrations of proteins.
Clinical presentation of pineal masses is usually related to the anatomy of the region. These tumors can often obstruct the sylvian aqueduct leading to hydrocephalus, with increased intracranial pressure and typically related symptoms, including headaches, nausea, vomiting and cognitive dysfunction. Moreover, pineal tumors can cause pressure on the superior colliculus, causing Parinaud syndrome or dorsal midbrain syndrome with vertical gaze palsy, light-near dissociation of the pupils, and convergence retraction nystagmus.

A study by Jennings et al [4] emphasizes the role of an accurate staging of the disease, showing the close relationship between survival and the extent of tumor. MRI of the brain and spine and spinal fluid cytology play an important role in the staging of this neoplasm, together with a careful physical examination of the patient.

Treating pineal region tumors generally requires a precise definition of the tumor histology, as long as the gold standard therapy and the related prognosis can be different for the various tumor types [5].

Radiotherapy represents an important treatment to be administered to all patients with pineal region tumors. Treatment volume and dose should be tailored to the specific tumor type. However, concerning PTPR, there is no current standard treatment options beyond gross total resection.

Our aim is to analyze the role of radiation therapy after partially resected PTPR.

\section{Case report}

In May 2012, a 27-year old woman presented with multiple episodes of collapse without loss of consciousness. For that reason, she underwent a first brain MRI showing a hyperintense T1-weighted lobulated mass in the pineal area, measuring $18 \times 19 \times 24 \mathrm{~mm}$, which was compressing quadrigeminal lamina and causing obstructive hydrocephalus. In January 2013, endoscopic third ventriculostomy was performed together with a biopsy of the lesion; the histological pattern was characterized by the presence of cells with oval or

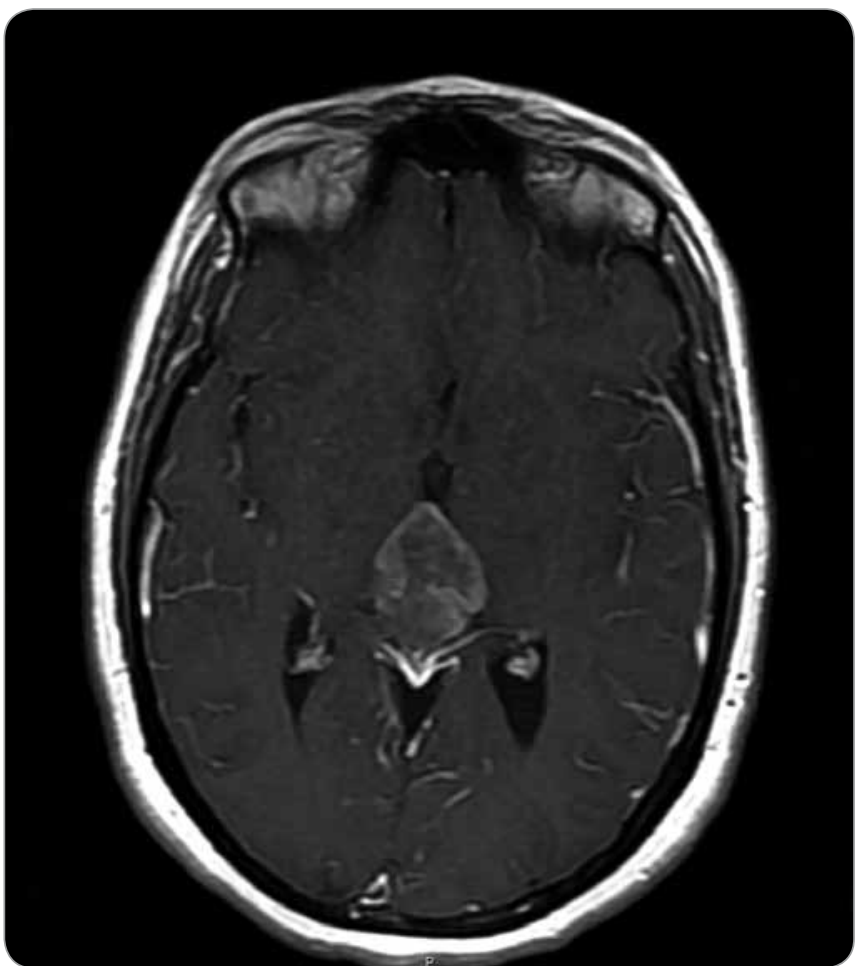

Fig. 1. Preoperative transversal T1 MRI constrast enhanced section showing the pineal mass (max. diameter of $3.9 \mathrm{~cm}$ ).

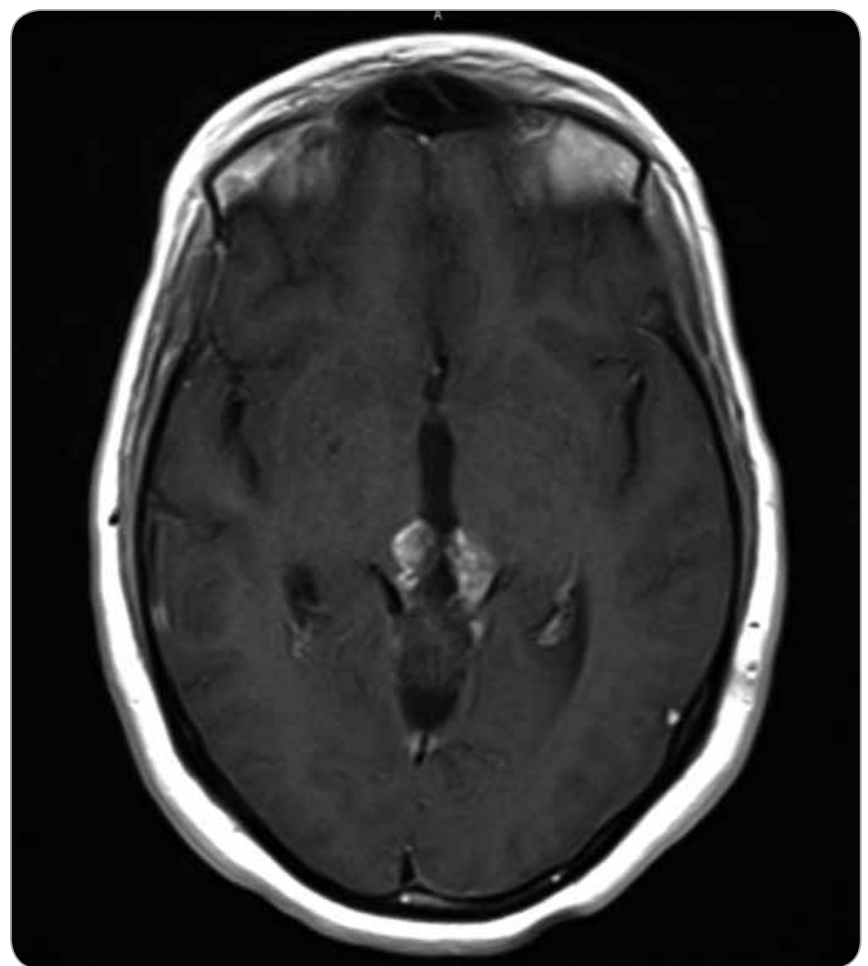

Fig. 2. Postoperative transversal T1 MRI constrast enhanced section of the gross residual tumor (max. diameter of $2.6 \mathrm{~cm}$ ). 
round nuclei and dispersed chromatin, organized in rosette-like structures. In the immunohistochemical stains, cells showed positive expression of synaptophysin, and a first diagnosis of Pineocytoma (grade I WHO) was made. During the period following surgical procedure, the patient experienced relief of symptoms. A postoperative MRI was performed 5 weeks after the third ventriculostomy and showed no volumetric changes of the lesion; the patient entered a follow-up program consisting of a MRI scan every 3 months, showing a progressive enlargement of the lesion. In November 2013, the patient began to suffer from headaches, diplopia and referred lower vision from the left eye; at that moment, the longest diameter of the tumoral mass was measuring $3.9 \mathrm{~cm}$ (Fig. 1). A suboccipital craniotomy was executed for the subtotal excision of the tumor, and the histological examination of the surgical specimen revealed round nuclear cells organized in papillary structures, seldom mitosis, vascular hyalinization and focal necrosis. Immunohistochemistry showed positivity for cytokeratin MNF 116 , GFAP and synaptophysin, while it showed negativity for OLIG2. Ki67 was $5 \%$. Based on these features, a diagnosis of PTPR was made. A postoperative MRI suggested persistence of the FLAIR hyperintense mass on the third ventricle wall, which was now measuring $26 \mathrm{~mm}$ and showing vivid enhancement after administration of contrast (Fig. 2). A neurological examination, which was executed one week after the surgical intervention, documented an objective difficulty for the patient in standing still; for this reason, the patient was transferred to the neurofunctional rehabilitation department, from which she was discharged after 2 weeks. Visual field test was also performed postoperatively, and showed no impairment of the field of view; patient vision was $8 / 10$ on the left side and $10 / 10$ on the right side, in a scale of 10 indicating the best and 0 indicating the worst visual acuity conditions.

The patient was referred to our Radiotherapy Department in January 2014, and we planned radiation therapy

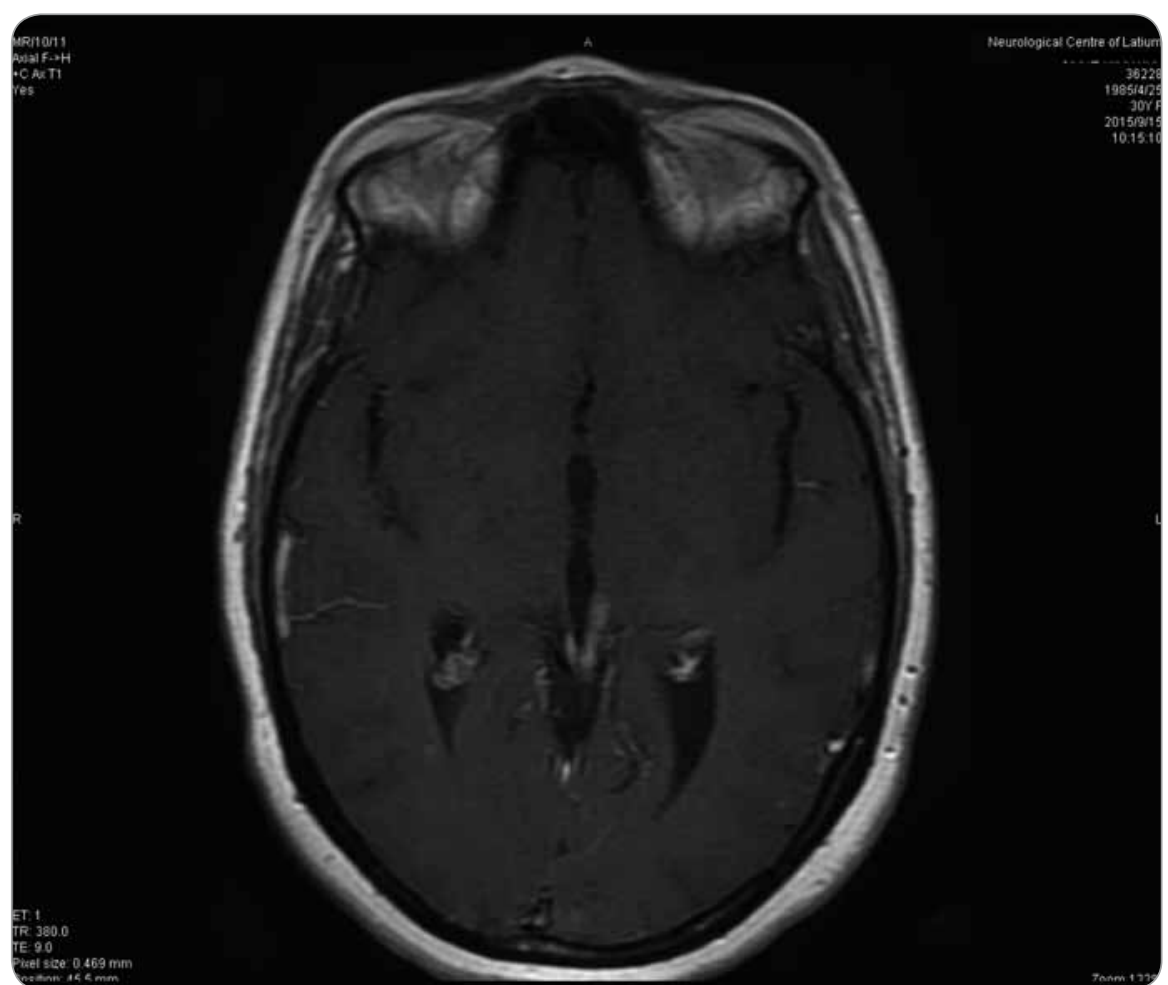

Fig. 3. Transversal T1 MRI constrast enhanced section at 33 months from surgery.

8 weeks after surgery. The patient was immobilized with a thermoplastic mask (Head Mask R-PRT3, Klarity). For planning purposes, we performed a CT scan with contrast ( $2.5 \mathrm{~mm}$ slice thickness) in the axial mode. Postoperative MRI study (T1-weighted with contrast) was used for image registration with the planning CT. Clinical target volume (CTV), consisting of the contrast enhanced lesion plus a $5 \mathrm{~mm}$ margin, and organs at risk (lens, eyes, brainstem, optic nerve, chiasm) were contoured. Planning target volume (PTV) was obtained with an isotropic $3 \mathrm{~mm}$ expansion of the CTV.

Treatment plan was produced on Pinnacle3 version 8.0m (Philips Medical Systems, Crawley, UK).

The radiotherapy regimen used in the current case included the administration of $59.4 \mathrm{~Gy}$ in 33 daily fractions of $1.8 \mathrm{~Gy}$ (5 days a week). The treatment was delivered with five conformal shaped treatment fields $(6 \mathrm{MV})$ using the multileaf collimator $(1 \mathrm{~cm}$ leaf width at the isocenter) of an Elekta Standard Linear Accelerator (Elekta Linac Precise). We performed daily image guidance using a set of orthogonal portal images.
The patient was monitored during treatment and then periodically by neurologic examination.

After a follow-up period of 41 months from the second operation (39 months from adjuvant radiotherapy (RT)), no adverse effects have been observed. The patient is currently asymptomatic and complete response was documented on a recent $\mathrm{MRI}$, according to the Response Evaluation Criteria In Solid Tumors (RECIST) criteria [6]. In particular, we noticed a gradual reduction of the enhancement of the irradiated lesion, associated with a progressive reduction of the residual tumor itself, and finally the complete response (Fig. 3).

\section{Discussion}

Papillary tumor of the pineal region is a rare and recently recognized neoplasm, which was first described in 2003 by Jouvet et al [1], and codified officially by the WHO only in 2007 [2]. The histopathology of these tumors resembles those of ependymomas and choroid plexus tumors, so that in the past this tumor entity was frequently misdiagnosed.

In the literature, there is no agreement among authors about the optimal 
therapeutic strategy for these uncommon lesions. The extent of surgical resection seems to be the only variable, which is associated with a better overall survival (OS) and recurrence. In a large retrospective multicenter study [7], data from 44 patients diagnosed with PTPR were analyzed in order to assess clinical factors and treatment choices, which could have an impact on the prognosis. Thirty-two out of the 44 patients were still alive after a median follow-up of 63.1 months. OS was $84.5 \%$ after 24 months, and at the univariate analysis, it was influenced only by age and type of surgery (gross total resection vs. partial resection vs. biopsy). Progression-free survival (PFS) was $68.9 \%$ after 24 months and $26.6 \%$ after 72 months. PFS was not influenced by age, sex or adjuvant treatment; $64 \%$ of the patients received radiotherapy and $18 \%$ received chemotherapy, even if in the study it was not well specified if radiotherapy was delivered in the adjuvant setting or in the recurrent disease.

In general, because of the scarceness of the reported data available in the literature, there is a lack of consensus concerning the role of multimodality therapy. Some authors are strongly convinced that radiotherapy should be administered, as long as tumor recurrence is frequent, and mostly associated with incomplete resection and with histologic features (i.e. increased mitosis) [8].

In a recent systematic review published in the journal of European Society for Radiotherapy and Oncology (ESTRO), Mallick et al analyzed data of 127 patients diagnosed with pineal parenchymal tumors of intermediate differentiation (PPTID), a rare related disease also arising from the parenchyma of the pineal gland and characterized by a wide spectrum of aggressiveness. About one third of the patients included in the analysis received adjuvant radiotherapy, which was found to be a significant prognostic factor for OS [9].

Edson et al [8] analyzed the data of 8 patients with pineal region tumor, 7 of whom received radiotherapy. Adjuvant RT was administered in 5 patients, and salvage RT for radiographic progression after surgery was administered in 2 patients. In most cases, adjuvant RT targeted the operative bed. With a median follow-up period from radiation of 46 months (range 10-170 months), 2 patients (29\%) experienced recurrence after radiation, both outside of the radiation field. A second course of salvage RT for both patients provided no additional recurrences at last follow-up (range 16-39 months). Similarly to Fauchon et al [7], this study suggested that local recurrence risk after surgery is high and focal adjuvant RT should be considered, even after gross total resection.

In an important review by Poulgrain et al [10], they analyzed all reports of patients diagnosed with PTPR published in the English literature since 2010. Adjuvant RT was used in 44 patients, including whole brain irradiation, local irradiation, stereotactic linac radiosurgery and gammaknife radiosurgery. No radiation protocol was favored over others and many reports did not include details; 17 patients did receive adjuvant chemotherapy (CHT), mostly in the setting of disease recurrence or spinal dissemination; 16 patients underwent both RT and CHT.

No prospective studies have addressed the issues of different dose levels specifically for PTPR treatment. The external beam radiotherapy adjuvant regimen used in our current case included administration of $59.4 \mathrm{~Gy}$ in 33 fractions, and it is consistent with those reported in a previous study [11] for primary pineal tumors.

Some reports of good outcome after definitive RT alone are also reported in the literature. In particular, stereotactic radiotherapy has a great potential role as a single treatment modality in the therapeutic management of pineal tumors [12]. Tumor regression after definitive RT or even tumor disappearance was observed in other studies [12].
Formal consensus for managing patients with a diagnosis of PTPR is nonexistent. While surgery with gross tumor resection could represent the mainstay of treatment, patients who are diagnosed with these tumors have a high risk for local recurrence, which can occur also several years after definitive therapy.

Considering this tendency to recur, the role of adjuvant radiotherapy in the treatment of PTPR needs to be investigated in a large multicentric prospective trial with a long follow-up.

\section{References}

1. Jouvet A, Fauchon F, Liberski P et al. Papillary tumor of the Pineal Region. Am J Surg Pathol 2003; 27(4): 505-512.

2. Roncaroli F, Scheithauer BW. Papillary tumor of the Pineal Region and Spindle Cell Oncocytoma of the Pituitary: new tumor entities in the 2007 WHO Classification. Brain Pathol 2007; 17(3): 314-318. doi: 10.1111/j.1750-3639.2007.00081.x.

3. Louis DN, Perry A, Reifenberger G et al. The 2016 World Health Organization Classification of Tumors of the Central Nervous System: a summary. Acta Neuropathol 2016; 13(6): 803-820. doi: 10.1007/s00401-016-1545-1.

4. Jennings MT, Gelman R, Hochberg F. Intracranial Germ-Cell Tumors: natural history and pathogenesis. J Neurosurg 1985; 63(2): 155-167. doi: 10.3171/jns.1985.63.2.0155. 5. RuleWG, Schild SE. Pineal Tumors: Viewpoint- Fractionated Radiation Therapy. [online]. Available from: https://radiologykey.com/pineal-tumors-viewpoint-fractionatedradiation-therapy/.

6. Eisenhauer E A, Therasse P, Bogaerts J et al. New Response Evaluation Criteria in solid tumors: revised RECIST guideline (version 1.1). European Journal of Cancer 2009; 45(2): 228-247. doi: 10.1016/j.ejca.2008.10.026.

7. Fauchon F, Hasselblatt M, Jouvet A et al. Role of surgery, Radiotherapy and chemotherapy in papillary tumors of the pineal region: a multicenter study. J Neurooncol 2013; 112(2): 223-231. doi: 10.1007/s11060-013-1050-5.

8. Edson MA, Fuller GN, Allen PK et al. Outcomes after Surgery and Radiotherapy for Papillary Tumor of the Pineal Region. World Neurosurg 2015; 84(1): 76-81. doi: 10.1016/j.wneu.2015.02.031

9. Mallick S, Benson R, Rath GK. Patterns of care and survival outcomes in patients with pineal parenchymal tumor of intermediate differentiation: An individual patient data analysis. Radiother Oncol 2016; 121(2): 204-208.

10. Poulgrain K, Gurgo R, Winter C et al. Papillary tumor of the Pineal Region. J Clin Neurosci 2011; 18(8): 1007-1017. doi: 10.1016/j.jocn.2010.12.027.

11. Villà S, Miller RC, Krengli M et al. Primary Pineal Tumors: Outcome and prognostic factors--a study from the Rare Cancer Network (RCN). Clin Transl Oncol 2012; 14(11): 827-834. doi: 10.1007/s12094-012-0869-0.

12. Patel SK, Tomei KL, Christiano LD et al. Complete regression of Papillary Tumor of the Pineal Region after Radiation Therapy: case report and review of the literature. J Neurooncol 2012; 107(2): 427-434. doi: 10.1007/s11060011-0764-5 